\title{
The Red Sea and the Port of Clysma. A Possible Gate of Justinian's Plague
}

Costas Tsiamis, Effie Poulakou-Rebelakou and Eleni Petridou

\section{Summary}

The aim of this study is to present the sea and land commercial routes of the Byzantine Egypt and their role in the dissemination of the plague bacteria Yersinia pestis from the Red Sea to Mediterranean ports. The Mediterranean port of Pelusium was considered as the starting point of the first plague pandemic, according to the historical and archaeological data; the port of Clysma in the Red Sea, however, can also be assumed as possible entrance gate of the Yersinia pestis. Indeed, it is proposed that the port of Clysma is most likely to have been the gateway of Yersinia pestis in the Byzantine Egypt when the epidemic broke out, given its geographic position and close trade relationship at the time of the epidemic in Pelusium.

Keywords: Byzantium; Egypt; history of medicine; the plague

\section{Introduction}

The plague is an acute infectious disease caused by the organism Yersinia pestis. It is a zoonosis, mainly transmitted by the bite of infected fleas. In man the most common clinical presentation is bubonic plague. Other forms include septicaemic plague without bubo, pneumonic plague, meningitis and pharyngitis ${ }^{1}$. Plague is best known as a medieval pestilence, although it remains endemic in many parts of the world today ${ }^{2}$.

1 Smith/Thanh 1996.

2 Tikhomirov 1999, 11-41.

Costas Tsiamis, Department of Hygiene, Epidemiology and Medical Statistics, Medical School, Athens University, M. Asias 75, GR-Athens 115-27 (ctsiamis@med.uoa.gr).

Effie Poulakou-Rebelakou, Department of the History of Medicine, Medical School, University of Athens, M. Asias 75, GR-Athens 115-27 (efpoulrebel@med.uoa.gr).

Eleni Petridou, Department of Hygiene, Epidemiology and Medical Statistics, Medical School, Athens University, M. Asias 75, GR-Athens 115-27 (epetrid@med.uoa.gr). 
There have been three world pandemics: the Justinian's plague (6th century $\mathrm{AD}$ ), the Black Death (14th century AD) and the third pandemic during 19th century. The first pandemic (541-746) claimed a million of victims in Asia, Africa and Europe. The tendency of the Byzantine chroniclers to exaggerate the death tolls led most historians to avoid assigning numbers. However, death rates between 15 and $40 \%$ for specific regions and epidemics have been ventured, and it is estimated that from 542 to $700 \mathrm{AD}$ there was a population loss of 50 to $60 \%^{3}$. The Black Death (1347-1351) had killed at least 25 million people, approximately one-fourth of the population of Europe at the time ${ }^{4}$. This pandemic was the beginning of a number of outbreaks of plague which ravaged Europe and Africa in subsequent centuries. The third pandemic began in Canton and Hong Kong in 1894 and spread rapidly throughout the world, carried by rats aboard the swifter steamships that replaced slow-moving sailing merchant vessels ${ }^{5}$.

The narration of the first pandemic by contemporary Byzantine historians and chronicle writers highlights an important historical and epidemiological question: Where was the real gateway of the plague to Europe during the 6th century AD? According to Byzantine historian Procopius and eyewitness of the plague, the epidemic started from the Mediterranean city of Egypt, Pelusium ${ }^{6}$. It seems impossible that the disease was transferred to Pelusium from any other Mediterranean port. Had this happened, the automatic conclusion would be that there was already an endemic or epidemic outbreak in the Mediterranean. No historical source, however, mentions anything about the existence of such a disease in other Mediterranean cities before the start of the known epidemic. By studying the historical geography, the trading paths of the East and historical data, we will attempt to suggest a possible portal of the disease in Byzantine Egypt.

\section{Pelusium and the channel of Traianus}

The position of Pelusium is identified in the current city of Tell el-Farama, in the eastern delta of the mouth of the Nile, thirty kilometres from the entrance of the Suez Canal at Port Said. During Roman times Pelusium was in one of the eastern branches of the Nile Delta (Ostium Pelusiacum). Pelusium was about 4 kilometres from the shores of the Mediterranean and only a specific

3 Perry/Fetherston 1997.

4 Olea/Christakos 2005.

5 Tikhomirov 1999, 11-41.

6 Procopius/Haury/Wirth 1905, 249-259. 


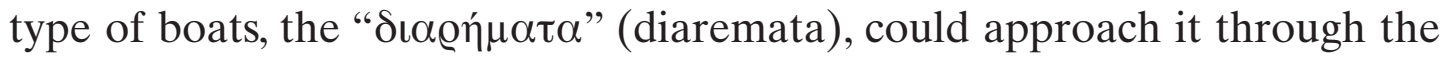
channels that crossed the marshes and swamplands that surrounded the city? The Port of Pelusium was overshadowed by the great Alexandria, from where ships left for Constantinople. Pelusium mainly served the maritime and land transport of goods such as salted food, oil and textiles to Palestine and Syria ${ }^{8}$. The two major ports in the Mediterranean, Alexandria and Pelusium, communicated with the Nile through channels. According to the descriptions of Procopius in his work "De Aedificiis" (On Constructions), the bulk of the Nile reached the small town Haireou which was linked to Alexandria through a channel ${ }^{9}$. In the eastern Delta, Pelusium was linked to the Nile through the city Bubastis ${ }^{10}$.

In the late Roman era, the eastern delta of the Nile hosted the channel of Traianus (Amnis Traianus), which crossed the Bitter Lakes of the Sinai and ended in the Red Sea ${ }^{11}$. The $\mathrm{C}^{12}$ carbon dating of river shells shows an age of around $1925 \pm 100$ years, an age that coincides with the changes of the eastern delta of the Nile in Traianus' era ${ }^{12}$. The channel of Traianus was not a new construction, but an improvement to the old "channel of the Pharaohs", starting from the city of Pithom in Sinai and ending in Babylon, Nile ${ }^{13}$. With the improvements to the old channel, the river Traianus, as the channel was often referred to, also connected the Bitter Lakes with the town of Bubastis ${ }^{14}$.

\section{The commercial importance of the Red Sea}

In the 6th century $\mathrm{AD}$, the Red Sea was the setting of a peculiar trade struggle between the Persian and the Byzantine Empire. The Byzantines exercised political influence on the kingdom of the Axumites (current Ethiopia) and the Persians on the Jewish kingdom of Himyarites (current Yemen) ${ }^{15}$. In the east, the Persians controlled the trade in the Persian Gulf but the sea was not completely under their control, so the Axumites (on behalf of the Byzantines) and Christian Himyarites traders reached Ceylon (the island was known to Byzantines as Taprovani) and southern India, as testified by the findings of

7 Procopius/Haury 1964, 171f.

8 Milani 1977, 216.

9 Procopius/Haury 1964, 171f.

10 Redmount 1995.

11 Sijpesteijn 1963.

12 Sneh 1973.

13 Uphill 1968.

14 Uphill 1968.

15 Laiou 2006, 346. 
Byzantine coins ${ }^{16}$. Since the 4 th century AD, thanks to the commercial agreements of emperor Constantius, Axum operated as an alternative commercial solution ${ }^{17}$. A journey from Africa or Arabia in India had many stopovers which were used in the following centuries by the Arabs, according to the descriptions of the Arab geographers Ibn Hawqal and Muqaddasi (10th century AD $)^{18}$.

The Byzantine ships received the goods of the Axumites and headed to the Red Sea ports. By the old Roman road, Via Hadriana, which joined the major ports of Berenike and Myos Hormos with the city of the Nile, Antinoopole, the goods reached the commercial stations of the river ${ }^{19}$. Myos Hormos was essentially the last accessible port, since beyond this navigation was very difficult (fig. 1$)^{20}$.

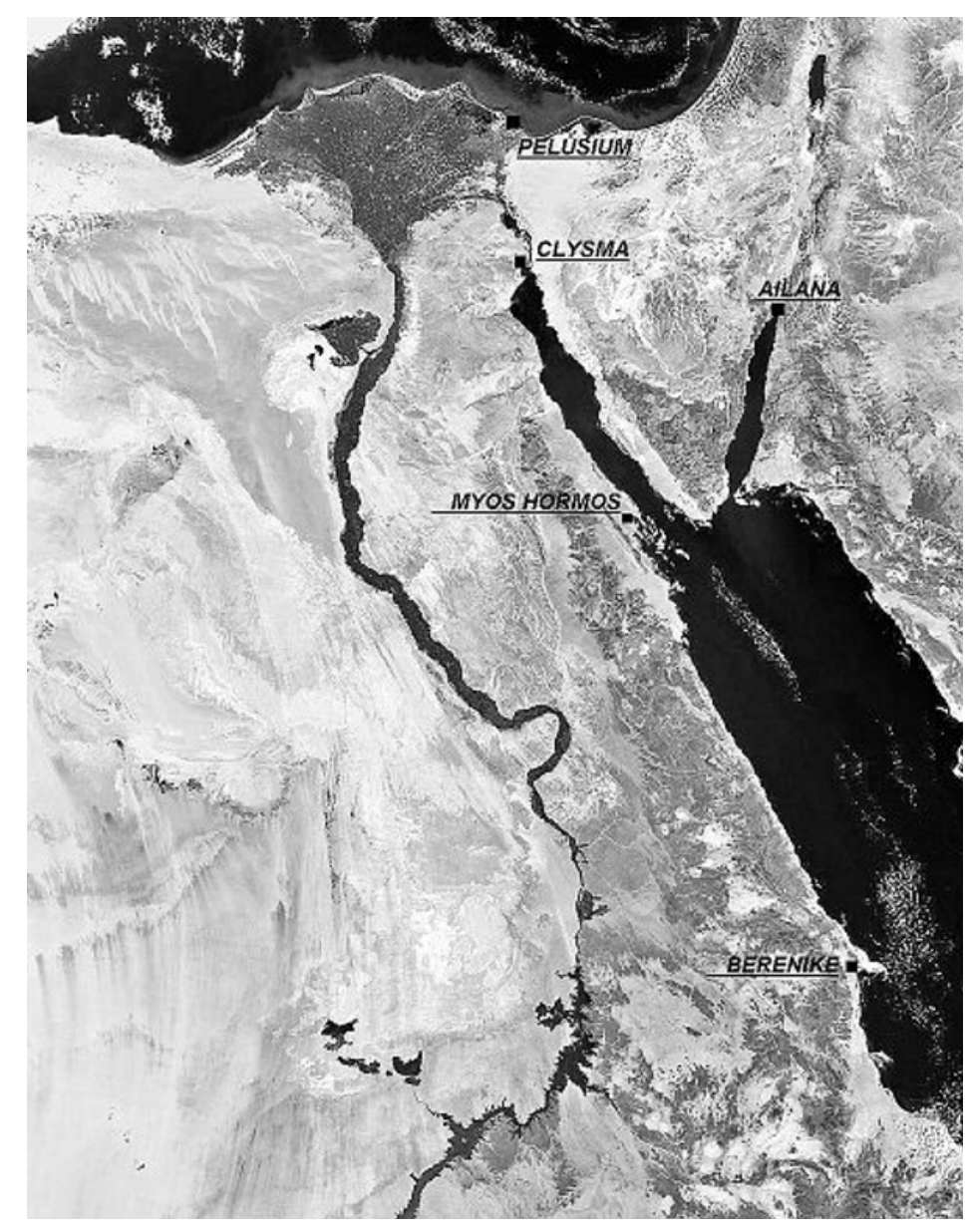

Fig. 1. The ports of the Red Sea during late Roman and early Byzantine times.

16 Laiou 2006, 346.

17 Laiou 2006; Philostorgius/Bidez/Winkelman 1972, 32f.; Casson 1989, $17 \mathrm{f}$.

18 Miquel 1977, 131-145.

19 Sidebotham 1997a; Sidebotham/Wendrich 2002.

20 Young 2001, 75-78. 


\section{The role of the ports of the Sinai Peninsula}

According to Procopius' narration, from Pelusium the disease spread west to Alexandria and gradually affected the rest of Egypt, and east to Palestine. The disease probably arrived in Alexandria in mid-September $541^{21}$. In the east, through the trade routes of Gaza, the disease affected Askalona and the towns in the region of the Negev, about one month after Pelusium, in the middle of August ${ }^{22}$. The information that the epidemic started from Pelusium limits the possible port portals of the plague to those in Sinai. The Sinai Peninsula had two ports, Ailana (current Aqaba) and Arsinoe ${ }^{23}$. From Ailana the caravans left for Palestine and Syria on the Nova Traiana course, while Arsinoe served the movement of goods to the Nile. Arsinoe, however, was abandoned due to the region's strong north-eastern winds. This resulted in the creation of a new port (about 5 kilometres to the west), to the side of the current Suez canal, the old port of Clysma ${ }^{24}$. Of course, Clysma faced the same problem of strong winds but a series of historical events rendered it perhaps the most important Red Sea port. Clysma was located in Sinus Hieroopoliticus (Gulf of Suez) and was a known port in ancient times, but was abandoned because of its shallow waters. The population of the city is unknown but we do have information on their water supply problems ${ }^{25}$. Between the 2 nd and 4th century AD, the surrounding area was uninhabited. In 383, we have a testimony of the pilgrim Egeria, surviving in the 11th century work by Petros Diakonus "Liber de locis sancti" 26 . According to Egeria's description the city was more of a frontier fortress than a busy port. Following the dredging works, Clysma developed into a port with great commercial activity that was responsible for the prosperity of "civitas modica ... ubi etiam de India naves veniunt"27. The choice of Clysma was far from random, as it was essentially the entrance to the channel of Traianus.

\section{The role of the Nile}

The Nile, the largest river in Africa, receives water from two sources - the White Nile in equatorial Africa and the Blue Nile in Ethiopia. The climatic

21 Kislinger/Stathakopoulos 1999.

22 Kislinger/Stathakopoulos 1999.

23 Sidebotham 1991, 78.

24 Mayerson 1996.

25 Mayerson 1996.

26 Peter the Deacon/Geyer 1965.

27 Milani 1977, 216. 
conditions in Central Africa play an important role, as it has been observed that the level fluctuations are linked not only with the quantity of water but also with the humid or dry tropical climate of equatorial Africa ${ }^{28}$. The level of the river is at its lowest from March to May. As of June the level begins to rise rapidly to reach its peak in mid-September ${ }^{29}$. It is no coincidence, then, that even the transfer of these, for the empire valuable, cereals of Egypt was planned between the two big annual flooding seasons of the Nile ${ }^{30}$. No matter how strange it may seem, in antiquity the Nile presented many difficulties in navigation and journeying in the river was a slow process. Since the time of the Pharaohs, ships travelled there only during the day. It is estimated that a boat in the Nile could travel a distance of 40 to $70 \mathrm{~km}$ a day ${ }^{31}$. The journey of 1545 kilometres from Sudan to the Mediterranean would take 28 days. Even the first border trading Byzantine station in the Nile, Elefantini (today Aswan), was thirty days by land from $\mathrm{Axum}^{32}$.

\section{Clysma as a possible gateway of the disease}

The channel of Traianus, like all other channels, was logically highly dependent on the level of the Nile. It has been argued that the channel of Traianus did not operate for centuries and that just a section was still used to carry fresh water from the Bitter Lakes to Clysma ${ }^{33}$. The theory is apparently strengthened by the evaluation of French engineers, in 1847, who believed that during the late Roman era, the trade of the Red Sea stopped during the summer months due to lack of water in the channels of the Nile ${ }^{34}$. The communication between Alexandria, Rozeta and Damietta is also considered to have been problematic in ancient times for at least six months a year ${ }^{35}$. However, in his monumental work "Historia Francorum", Gregory of Tours (6th century AD), trying to explain the Biblical Exodus, quotes a remarkable fact. Referring to testimonies by travellers of his time, he describes the existence of constructions from Babylon in the Nile to the Bitter Lakes in Sinai ${ }^{36}$. $\mathrm{He}$ also notes that Clysma was built not because the area was fertile but because that was where the river Traianus ended and that the port was used

28 Mikhailova 2001; Fraedrich/Bantzer 1991.

29 Eltahir 1996.

30 Nachtergael 1988.

31 Collin 2007, 17-46.

32 Procopius/Haury/Wirth 1905, 104.

33 Mayerson 1996.

34 Travaux de la Brigade Française 1847, 99.

35 Clot 1840, 495.

36 Gregorius Turonensis (Gregory of Tours)/Kruch 1937, 11. 
to transport products to Egypt, which then made their way to India ${ }^{37}$. It is very important to mention that during the medieval times the term "India" signifying any area in the Indian Ocean or Red Sea, the Byzantine sources often confuse India for Ethiopia. For example, Procopius gives separate information about the Indians and the Ethiopians merchants but at the same time informs us that the springs of the Nile River are in India ${ }^{38}$.

The time of the works in Clysma also manifest the importance of the channel, as this was used to bring supplies to workers and equip the ships anchored in the port ${ }^{39}$. Also, according to Gregory, these constructions took water from the Nile when the flow of water was from the west (Egypt) to the east (Sinai) ${ }^{40}$. This fact reinforces the view that the operation of the channel was inextricably linked with the fluctuations of the Nile. Given that the epidemic broke out in Pelusium in mid-July 541 and in Alexandria in midSeptember and taking into account the level of the Nile, we could create a geographical-historical link of the course of the disease, from Clysma to Pelusium and Alexandria, through the channel network.

The suggestion that at that time the port of Clysma could have acted as the gateway of Yersinia pestis is supported by a series of historical events. In the 6th century, the ports Myos Hormos and Berenike had been abandoned, while Via Hadriana had been destroyed ${ }^{41}$. The archaeological and anthropological findings in the region of the eastern desert of Egypt show a gradual aggregation of nomads from the 3rd century, who foraged the ports of the Red Sea and the Nile, while, in 524-525, we identify the last report on the operation of Berenike ${ }^{42}$. The upgrading of Clysma and hence its preference was reinforced by another historical event. Clysma protected an important commercial station in the Red Sea, the island Iotabe ${ }^{43}$. The Saracens had occupied the island and threatened the Byzantine trade and a campaign by Duke Aratios was required, in 534, for the Byzantines to re-occupy it ${ }^{44}$. Clysma therefore represented a guarantee for the safety of the island offering ships ready for war in an emergency. In the same period Clysma flour-

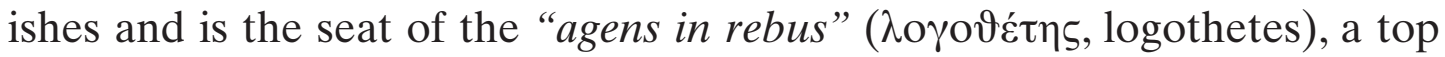
official who visited the kingdom of Axum once a year as ambassador of the Byzantine emperor ${ }^{45}$.

37 Gregorius Turonensis (Gregory of Tours)/Kruch 1937, 11.

38 Procopius/Haury 1964, 171f.; Procopius/Haury/Wirth 1905, 104.

39 Collin 2007, 17-46.

40 Gregorius Turonensis (Gregory of Tours)/Kruch 1937, 11.

41 Sidebotham/Zitterkopf 1997b.

42 Ward 2007.

43 Ward 2007.

44 Ward 2007.

45 Mayerson 1996. 
The mass abandonment of many ports on the coast of the Red Sea and the Nile shows the fear of the attacking nomads. It is likely that this fact contributed to the choice of this trade route from Axum to Clysma. The case of a direct link of Clysma with Pelusium along the Bitter Lakes must be considered a something of a problem. The main reason for this is the geography of the region with its scalding sun and lack of wells, which made travellers describe it as a "terrible desert" ${ }^{\text {" }}$. The findings also suggest the state's failure to protect the land roads of Sinai from the Saracens. The archaeological findings show numerous defence walls in the settlements of the peninsula, a fact obviously linked to the government's abandonment of the region of Sinai and the effort of the residents to protect it themselves ${ }^{47}$.

\section{Conclusions}

The pandemic had started at Pelusium in Egypt, but probably this port served merely as the distributing centre of the disease. Some of the trade roads in the area were simulated, with the help of historical and archaeological sources. The above suggests a vast commercial traffic in the Red Sea and the importance Clysma acquired during the 6th century AD. For historical reasons it is believed that Clysma is most likely to have been the gateway of Yersinia pestis in the Byzantine Egypt when the epidemic broke out. The time of the epidemic's occurrence at Pelusium, Clysma's geographic position and their close trade relationship strengthen this theory. Finally, the use of the channel of Traianus at the time of the epidemic is under question, without its operation being precluded however.

\section{Bibliography}

Casson, Lionel, The Periplus Maris Erythraei: text, translation and commentary (Princeton 1989) Clot, A., Aperçu général sur l'Egypte (Paris 1840)

Collin, Adams, Land transport in Roman Egypt. A Study of Economics and Administration in a Roman Province (Oxford 2007)

Eltahir, Elfatih, "El Niño and the natural variability in the flow of the Nile River", Water Recourses Research 32 (1996) 131-137

Fraedrich, Klaus/Carl Bantzer, "A note on fluctuations of the Nile River Flood Levels (715-1470)", Theoretical and Applied Climatology 44 (1991) 167-171

Gregorii Turonensis Opera. Decem Libri Historiarum (Historia Francorum), in: Bruno Krusch/ Wilhelm Levison (ed.), Monumenta Germaniae Historiae (Hannover 1937)

Kislinger, Ewald/Dyonisios Stathakopoulos, "Pest und Perserkriege bei Prokop. Chronologische Überlegungen zum Geschenen 540-545”, Byzantion 69 (1999) 76-98

46 Collin 2007, 17-46.

47 Ward 2007. 
Laiou, Angeliki, Economic History of Byzantium (Athens 2006)

Mayerson, Philip, "The port of Clysma (Suez) in transition from Roman to Arab Rule", Journal of Near Eastern Studies 55 (1996) 119-126

Mikhailova, Maria, "Hydrological Regime of the Nile Delta and Dynamics of its Coastline", Water Resources 28 (2001) 526-539

Milani, Celestina, Itinerarium Antonini Placentini - un viaggio in terra Santa del 560-570 d.C. (Roma 1977)

Miquel, André, L'Islam et sa civilization VII ${ }^{e}-X X^{e}$ siècle (Paris 1977)

Nachtergael, George, "Un aspect de l'environnement en Egypte gréco-romaine: les dangers de la circulation", Ludus Magistralis 2 (1988) 19-54

Olea, Richard/George Christakos, "Duration of Urban Mortality for the 14th century Black Death Epidemic", Human Biology 77 (2005) 291-303

Peter the Deacon, "Liber de locis sancti. Appendix ad Itineriarum Egeriae II", in: Paul Geyer (ed.), Itineriaria et Alia Geographica, Corpus Christianorum Latina 175 (Leipzig 1965) 93-103

Perry, Robert/Jacqueline Fetherston, "Yersinia pestis: etiologic agent of plague", Clinical Microbiology Review 10 (1997) 35-66

Philostorgius, Kirchengeschichte, Jakob Bidez/Frank Winkelman (eds) (Berlin 1972)

Procopii Caesariensis, Opera Omnia De Bellis, Libri I-II, Jakob Haury/Gerhard Wirth (eds) (Leipzig 1905)

- Opera Omnia, De aedificiis, Liber VI, Jakob Haury (ed.) (Leipzig 1964)

Redmount, Carol, "The Wadi-Tumilat and the "canal of Pharaohs", Journal of Near Eastern Studies 54 (1995) 127-136

Sidebotham, Steven, "Ports of the Red Sea and the Arabia-India trade", in: Vimala Begley/ Richard De Puma, Rome and India: the ancient sea trade (Wisconsin 1991) 78

- "Caravans across the Eastern Desert of Egypt: recent discoveries on the Berenike-Apollonopolis Magna-Koptos road", in: Alessandra Avanzini (ed.), Profumi d'Arabia, Atti del convegno (Roma 1997a) 385-393

- /Roland Zitterkopf, "Survey of the Via Hadriana: the 1996 season", Bulletin de l'Institut Français d'Archéologie Orientale 2 (1997b) 221-237

- /Willemina Wendrich, "Berenike: archaeological fieldwork at a Ptolemaic-Roman port on the Red Sea coast of Egypt 1999-2000", Sahara 13 (2002) 31-44

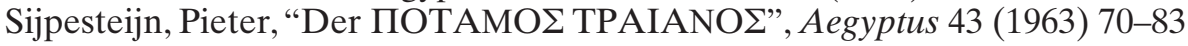

Smith, Michael/Nquyen Thanh, "Plague", in: Gordon Cook (ed.), Manson's Tropical Diseases (London 1996) 918-924

Sneh,Amihan/Tuvia Weissbrod, “Nile Delta: the defunct Pelusiac branch identified”, Science 180 (1973) 59-61

Tikhomirov,Evgueni, "Epidemiology and Distribution of Plague", in:David Dennis (ed.), Plague Manual: Epidemiology, Distribution, Surveillance and Control (Geneva 1999)

Travaux de la Brigade Française, Rapport de l'ingénieur (Paris 1847)

Uphill, Eric, "Pithom and Ramses: their location and significance", Journal of Near Eastern Studies 27 (1968) 291-315

Ward, Walter, "Aila and Clysma: The rise of northern ports in the Red Sea in late antiquity", in: Janet Starkey et al. (eds), Natural Resources and Cultural Connections of the Red Sea (British Archaeological Reports International Series 2007) 161-171

Young, Gary, Rome's Eastern Trade: International Commerce and Imperial Policy 31 B.C.-305 A.D. (London 2001) 